\title{
20- 2020 Avrupa Ortak Öneriler Çerçevesi (CEFR) metninde bulunan dilbilgisel yeterliklerin incelenmesi
}

\section{Gökhan Haldun DEMİRDÖVEN}

APA: Demirdöven, G. H. (2021). 2020 Avrupa Ortak Öneriler Çerçevesi (CEFR) metninde bulunan dilbilgisel yeterliklerin incelenmesi. RumeliDE Dil ve Edebiyat Araştırmaları Dergisi, (Ö10), 339351. DOI: 10.29000/rumelide.1011952.

$\ddot{\mathbf{O z}}$

Avrupa Konseyi’ne üye olan ülkeler arasındaki yabancı dil öğrenim ve öğretim süreçlerini sistematik bir hale getirmeyi amaçlayan Diller İçin Avrupa Ortak Öneriler Çerçevesi’nin (AOÖÇ), son sürümü 2020 yılının Nisan ayında AOÖÇ Tamamlayıcı Cilt başlı̆̆ıyla yayımlanmıştır. Yabancı bir dildeki iletişimsel dil yeterlikleri kazanma süreçlerini bir kompozisyon şeklinde sunması bakımından önem teşkil eden AOÖÇ, yabancılara Türkçe öğretimi disiplin alanı için bir başvuru metni olma niteliği taşımaktadır. İletişimsel dil yeterliklerinin bir bileşeni olan dilbilgisel yeterlikler, uygun ve anlamh iletileri oluşturabilen ve ifade edebilen biçimsel araç bilgisi ve bu araçları kullanma yeterliği olarak tanımlanır (TELC, 2013). Bu yeterlikler, söz konusu dile özgü kurallara uygun, iyi biçimlendirilmiş ifade ve cümleler yapılandırabilme becerisi ile doğrudan ilişkili olmasından dolayı iletişimin gerçekleşebilmesi açısından köprü görevi üstlenmektedir. Alan yazın incelemesi yapıldı̆̆ında AOÖÇ’nin ilk (2001) ve son (2020) sürümleri arasında dilbilgisel yeterlikler bağlamında karşılaştırmalı bir çalışmanın bulunmadığı tespit edilmiştir. İlgili bağlamdan yola çıkarak bu çalışmada, iletişimsel dil yeterliklerinin bir alt başlığını oluşturan dilbilgisel yeterliklerin incelenmesi amaçlanmış olup AOÖÇ’nin ilk sürümünde ifade edilen (2001) dilbilgisel yeterlikler ile son sürümünde (2020) belirtilen dilbilgisel yeterliklerin karşılaştırılması hedeflenmiştir. Çalışma kapsamında elde edilen veriler, nitel araştırma tekniklerinden biri olan doküman incelemesi yoluyla toplanmıştır. Araştırma sonuçları, AOÖÇ'de dilbilgisel yeterlikler kapsamında verilen ölçeklerde tanımlayıcı ve dil düzeyleri bağlamında birtakım değişiklikler yapıldığına işaret etmektedir. Tanımlayıcı bağlamında gerçekleştirilen değişikliklerin, en fazla Sesbilgisel Hâkimiyet ölçeği üzerinde yapıldı̆̆ı görülürken; Sesbilgisel Hâkimiyet ölçeği hariç diğer ölçeklere A1 Öncesi dil düzeyinin eklendiği ve Genel Dilsel Araçlar Alanı ve Dilbilgisel Doğruluk ölçeklerinde ilgili dil düzeyine yönelik mevcut tanımlayıcıların da oluşturulmuş olduğu tespit edilmiştir.

Anahtar kelimeler: Diller İçin Avrupa Ortak Öneriler Çerçevesi 2020, dilbilgisel yeterlikler, yabancı dil öğretimi

\section{Analyzing the linguistic competencies contained in the 2020 Common European Framework of Refrence (CEFR)}

\begin{abstract}
The latest version of the Common European Framework for Languages (CEFR), which aims to systematize the foreign language learning and teaching processes among the member states of the Council of Europe, was published in April 2020 with the title of CEFR Supplementary Volume. CEFR, which is important in terms of presenting the process of acquiring communicative language
\end{abstract}

Arş. Gör., Sakarya Üniversitesi, Eğitim Fakültesi, Türkçe ve Sosyal Bilimler Eğitimi, Türkçe Eğitimi ABD (Sakarya, Türkiye), gdemirdoven@sakarya.edu.tr, ORCID ID: oooo-ooo1-7892-5458 [Araştırma makalesi, Makale kayıt tarihi: 25.09.2021-kabul tarihi: 20.10.2021; DOI: 10.29000/rumelide.1011952]

Adres | Address

RumeliDE Dil ve Edebiyat Araştırmaları Dergisi $\quad$ RumeliDE Journal of Language and Literature Studies Osmanağa Mahallesi, Mürver Çiçeği Sokak, No:14/8 $\quad$ Osmanağa Mahallesi, Mürver Çiçeği Sokak, No:14/8

Kadıköy - ISTANBUL / TÜRKIYE 34714 Kadıköy - ISTANBUL / TURKEY 34714 e-posta: editor@rumelide.com e-mail: editor@rumelide.com, tel: +90 505 7958124, +90 2167730616 phone: +90 505 7958124, +90 2167730616 
proficiency in a foreign language in the form of a composition, is a reference text for the discipline of teaching Turkish to foreigners. Linguistic competencies which are a component of communicative language competencies are defined as the knowledge of formal means and the ability to use these means that can create and express appropriate and meaningful messages (TELC, 2013). Since these competencies are directly related to the ability to construct well-formed expressions and sentences in accordance with the rules specific to the language in question, they act as a bridge in terms of communication. When the literature review was made, it was determined that there was no comparative study in the context of linguistic competencies between the first (2001) and the last (2020) versions of CEFR. Based on the relevant context, in this study, it was aimed to examine the linguistic competencies that constitute a sub-title of communicative language competencies, and it was aimed to compare the grammatical competencies expressed in the first version (2001) and the linguistic competencies stated in the last version (2020). The data obtained within the scope of the study were compiled through document analysis, which is one of the qualitative research techniques. The results of the research indicate that some changes have been made in the descriptive and language levels in the scales given within the scope of linguistic competencies in the CEFR. It is detected that the changes made in the context of the descriptor were mostly made on the Phonological Control scale; It was determined that Pre-A1 language level was added to other scales except Phonological Control scale, and existing descriptors for the relevant language level were also created in the General Linguistic Range and Grammatical Accuracy scales.

Keywords: Common European Framework of Reference for Languages 2020, linguistic competencies, foreign language teaching

\section{Giriş}

Günümüz dünyası koşullarında ele alındığında yabancı bir dil ya da birçok dil bilmek, kişi için olumlu bir donanım olmaktan ziyade bir gereklilik halini almıştır. Bilişim teknolojilerinde meydana gelen gelişmeler; iletişim materyallerini zenginleştirmiş, coğrafi sınırları ortadan kaldırmış ve birbirinden çok farklı fiziki konumlarda bulunan insanların birbirlerine ulaşabilirliğini anlık zaman dilimlerine düşürmüştür. Dolayısıyla farklı toplumlar arası etkileşim önem kazanmış ve yabancı dil yeterliklerine sahip olmak, bireyde mevcut olması gereken bir yeterlik olarak görülmeye başlanmıştır.

Birliği içinde bulunan vatandaşların gerek ekonomik gerekse kültürel açıdan birbirlerine daha çok yakınlaşmasını amaçlayan Avrupa, bu doğrultuda ilk adımlarını 1971'de Avrupa Konseyi Kültürel İşbirliği Komisyonu aracılı̆̆ıyla atmış ve Avrupa Konseyi’ne üye olan ülkelerin birbirlerinin dillerini daha bilimsel bir temelde öğrenebilmeleri için Diller İçin Avrupa Ortak Öneriler Çerçevesi’nin (AOÖÇ) ilk çalışmalarını başlatmıştır.

AOÖÇ; kapsamlı bir taslak hazırlama, pilot uygulama ve danışma sürecinin ardından tam metin haliyle ilk kez 2001 yılında yayımlanmış ve sonrasında günümüz yabancı dil eğitimi gereksinimleriyle ilgili olarak içerisinde bulunan ölçek ve tanımlayıcılara yönelik getirilen eleştiriler (Alderson, 2007; Wisniewski, 2014) bağlamında değişiklikler yapılarak sırasıyla Ekim, 2017'de AOÖÇ Yeni Tanımlayıcılarla Tamamlayıcı Geçici Cilt (CEFR Companion Volume with new Descriptors Provisional Edition); Şubat, 2018'de AOÖÇ Yeni Tanımlayıcılarla Tamamlayıcı Cilt (CEFR Companion Volume with new Descriptors) ve son olarak Nisan, 2020'de AOÖÇ Tamamlayıcı Cilt (CEFR Companion Volume) başlıkları ile güncellenmiştir.

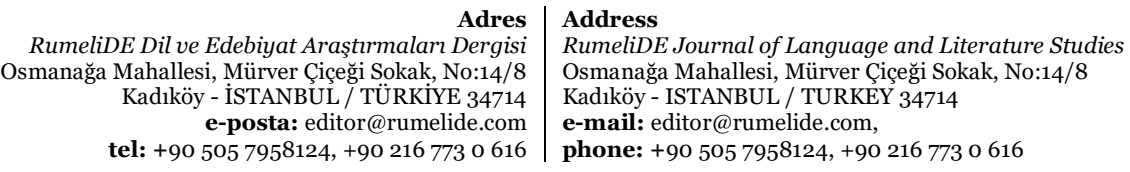

RumeliDE Journal of Language and Literature Studies

Osmanağa Mahallesi, Mürver Çiçeği Sokak, No:14/8

Kadıköy - ISTANBUL / TURKEY 34714

e-mail: editor@rumelide.com,

phone: +90 505 7958124, +90 2167730616 
Yayımlandığı ilk sürümünden bu yana yabancı dil öğrenim süreçlerini, çeşitli dil düzeyleri göre dilsel yeterlikler kapsamında sistematik bir alt yapıya oturtması yönüyle dikkat çeken AOÖÇ, yabancı dil öğrenmek isteyen kişilerin hangi düzeyde hangi becerileri sergilemesi gerektiğini kapsamlı bir şekilde betimlemesi bakımından bir referans metin olma özelliği taşımaktadır. Bu bağlamda birçok yabancı dilin öğretiminde olduğu gibi yabancllara Türkçe öğretimi disiplin alanında da bir başvuru metni olarak kabul edilmesi açısından önem teşkil etmektedir.

Dil öğrenenler, iletişimsel amaçlarını gerçekleştirebilmek için hem genel yeteneklerinden hem de özel olarak dille ilişkili iletişimsel yeterliklerinden yararlanırlar (TELC, 2013). AOÖÇ'de belirtilen iletişimsel yeterlikler; Dilbilgisel Yeterlikler, Toplum Dilbilgisel Yeterlikler ve Pragmatik Yeterlikler başlıkları altında verilen ölçeklerdeki çeşitli tanımlayıcılardan oluşmaktadır.

İletişimsel dil yeterliklerinin bir bileşeni olan dilbilgisel yeterlik, uygun ve anlamh iletileri oluşturabilen ve ifade edebilen biçimsel araç bilgisi ve bu araçlar kullanma yeteneği (TELC, 2013, s. 110) olarak tanımlanır. Bu yeterlik, söz konusu dile özgü kurallara uygun, iyi biçimlendirilmiş ifade ve cümleler üretme ve bu ifade ve cümleleri tanıma yeteneği ile doğrudan ilişkili olmasından dolayı iletişimin gerçekleşebilmesi açısından büyük önem taşımaktadır.

İlgili dile özgü anlamlı seslerden oluşan biçimbirimler sırasıyla; kelime, kelime öbekleri ve cümleleri meydana getirir. Bu düzen, sesbilimsel ve dilbilgisel unsurlar etrafında şekillenir. Dilbilgisel dizge, bu düzenin; dilbilgisi kuralları çerçevesinde bir bütün oluşturmasını sağlar (Peçenek, 2008). Dolayısıyla bu kurallar bütününün, biçimbirimlerin birleşerek dilde anlamlı bir ahenk haline dönüşmesi için hangi evrelerden geçmesi gerektiğinin çerçevesini çizip dilin omurgasını oluşturduğunu (Hassan, 2001) söyleyebiliriz.

Alan yazın incelemesi yapıldığında AOÖÇ’nin (2001) ve (2020)sürümleri arasında dilbilgisel yeterlikler bağlamında karşılaştırmalı bir çalışmanın bulunmadığı tespit edilmiştir. İlgili bağlamdan yola çıkarak bu çalışmada iletişimsel dil yeterliklerinin bir alt başlı̆̆ını oluşturan dilbilgisel yeterliklerin incelenmesi amaçlanmış olup AOÖÇ’nin ilk sürümünde ifade edilen (2001) dilbilgisel yeterlikler ile son sürümünde belirtilen dilbilgisel yeterliklerin karşılaştırılması hedeflenmiştir.

\section{Yöntem}

Çalışmada, araştırmanın kapsamı ve içeriği gereği nitel araştırma yöntemi kullanılmıştır. Bu doğrultuda araştırmanın modelini, nitel araştırma desenlerinden biri olan betimsel araştırma modeli oluşturmaktadır. Betimsel araştırmalar, olay ve durumların ayrıntılı bir şekilde tasvir edilmesi amacıyla gerçekleştirilir (de Vaus, 2001). Bu doğrultuda çalışmada; AOÖÇ Tamamlayıcı Cilt, 2020 (CEFR Companion Volume) sürümündeki dilbilgisel yeterliklere yönelik ölçek ve tanımlayıcılar mercek altına alınarak AOÖÇ, 2001 sürümündeki dilbilgisel yeterliklere yönelik ölçek ve tanımlayıcılarla karşlaş̧ırılmıştır.

\subsection{Verilerin toplanması}

Araştırmanın verileri, nitel araştırma veri toplama yöntemlerinden biri olan doküman incelemesi yoluyla elde edilmiştir. Doküman incelemesini, araştırılmak istenen konuya yönelik yazılı ya da görsel dokümanların içeriğini detaylı ve sistemli bir şekilde inceleme işlemi olarak ifade edebiliriz (Wach, 2013; Yıldırım ve Şimşek, 2016). Araştırma, Diller İçin Avrupa Ortak Öneriler Çerçevesi Öğrenim, Öğretim ve Değerlendirme, 2001 (Common European Framework of Reference for Languages: Learning, Teaching,

\footnotetext{
Adres | Address

RumeliDE Dil ve Edebiyat Araştırmaları Dergisi $\quad$ RumeliDE Journal of Language and Literature Studies

Osmanağa Mahallesi, Mürver Çiçeği Sokak, No:14/8 $\quad$ Osmanağa Mahallesi, Mürver Çiçeği Sokak, No:14/8

Kadıköy - ÍSTANBUL / TÜRKIYE 34714 Kadıköy - ISTANBUL / TURKEY 34714

e-posta: editor@rumelide.com e-mail: editor@rumelide.com,

tel: +90 505 7958124, +90 2167730616 phone: +90 505 7958124, +90 2167730616
} 
Assessment) ve Diller İçin Avrupa Ortak Öneriler Çerçevesi Öğrenim, Öğretim ve Değerlendirme Tamamlayıcı Cilt, 2020 (Common European Framework of Reference for Languages: Learning, Teaching, Assessment Companion volume) metinlerinde yer alan dilbilgisel yeterliklere yönelik ölçek ve tanımlayıcılar üzerine gerçekleştirilmiştir.

\subsection{Verilerin analizi}

Çalışma kapsamında elde edilen verilerin analizinde betimsel analizden yararlanılmıştır. Betimsel analiz; verilerin, önceden belirlenmiş temalar doğrultusunda özetlenip yorumlanmasına dayanmaktadır (Yıldırım ve Şimşek, 2016). İlgili bağlamda veri kaynakları mercek altına alınarak; Genel Dilsel Araçlar Alanı Ölçeğinde Yapılan Güncellemeler, Kelime Dağarcı̆̆ı Alanı Ölçeğinde Yapılan Güncellemeler, Dilbilgisel Doğruluk Ölçeğinde Yapılan Güncellemeler, Kelime Dağarcı̆̆ı Hâkimiyeti Ölçeğinde Yapılan Güncellemeler, Sesbilgisel Hâkimiyet Ölçeğinde Yapılan Güncellemeler ve Yazım Yeterliği Hâkimiyeti Ölçeğinde Yapılan Güncellemeler başlıkları oluşturulmuş ve araştırmanın bulguları, bu başlıklar altında sunulmuştur. Sunulan bulgular, veri kaynakları karşılaştııılarak tablolaştırılarak yorumlanmıştır.

\section{Bulgular}

Araştırmanın bulguları; Genel Dilsel Araçlar Alanı, Kelime Dağarcığı Alanı, Dilbilgisel Doğruluk, Kelime Dağarcığı Hâkimiyeti, Sesbilgisel Hâkimiyet ve Yazım Yeterliği Hâkimiyeti ölçeklerinde yapılan güncellemeler olmak üzere altı başlık altında incelenmiştir. ${ }^{2}$

\subsection{Genel dilsel araçlar alanı ölçeğinde yapılan güncellemeler}

Bu ölçek; dil öğrenenlerin, dilsel araçlar kullanımında gösterdikleri gelişmelerin sınıflandırılmasıyla ilgilidir. Ölçekte işlevselleştirilen kavramlar şunları içerir:

- Düzey aralı̆̆ı/yayılımı: A1'den B2'ye, sonra sınırsız;

- Dil türü: Ezberlenmiş cümlelerden; düşünceleri eksiksiz şekilde biçimlendirmek, vurgulamak, farklılaştırmak ve belirsizliği ortadan kaldırmak için çok geniş bir dil yelpazesine;

- Sınırlamalar: Alışıldık olmayan durumlarda sık sık yaşanan anlamsal bozulmadan/yanlış anlamadan; söylemek istediklerini kısıtlamak zorunda olmadan ifade etmeye (AOÖç, 2020).

Tablo 1'de Genel Dilsel Araçlar Alanı ölçeğine yer verilmiştir.

Tablo 1. Genel dilsel araçlar alanı (AOÖÇ, 2020, s. 130-131).

Düşünceleri eksiksiz şekilde ifade etmek, onlara vurgu yapmak, onları farklılaştırmak ve anlam belirsizliği ortadan kaldırmak için çok geniş bir dil yelpazesi bağlamında kapsamlı ve güvenilir bir dilden yararlanabilirler. Söylemek istediklerini anlatırken kısıtlama yapmak zorundaymış izlenimini uyandirmazlar (2001; 2020).

Çok çeşitli, karmaşık dil bilgisi yapılarını uygun şekilde ve oldukça esnek bir şekilde kullanabilirler

C1 $\quad$ (2020). dağarcı̆̆ından uygun bir ifade seçebilirler (2001; 2020).

Söylemek istediklerini kısıtlıyormuş gibi gözükmeden kendini açık bir şekilde ifade edebilirler (2001; 2020).

Tanımlayıcıların sonunda bulunan parantez içi bilgilerde ilgili tanımlayıcıların AOÖÇ’nin hangi sürüm veya sürümlerinde yer aldığı belirtilmektedir.

RumeliDE Dil ve Edebiyat Araştırmaları Dergisi Osmanağa Mahallesi, Mürver Çiçeği Sokak, No:14/8 Kadıköy - ISTANBUL / TÜRKIYE 34714 e-posta: editor@rumelide.com tel: +90 $5057958124,+902167730616$

Address

RumeliDE Journal of Language and Literature Studies Osmanağa Mahallesi, Mürver Çiçeği Sokak, No:14/8

Kadıköy - ISTANBUL / TURKEY 34714

e-mail: editor@rumelide.com,

phone: +90 505 7958124, +90 2167730616 
Yeterli sayıda dilsel araca sahip olduklarından sözcükleri aramadan ve birkaç birleşik cümle yapısını da kullanarak anlaşılır biçimde betimlemelerle görüşlerini ifade edebilir ve ayrıntılarıyla açılkayabilirler (2001; 2020).

Tahmin edilemeyen durumları tanımlamak, bir fikir veya problemdeki ana noktaları makul bir hassasiyetle açlklamak ve müzik ve film gibi soyut veya kültürel konularda düşüncelerini ifade etmek için yeterli bir dil dağarcığına sahiptirler (2001; 2020).

B1

Aile, hobi, ilgi alanları, meslek, seyahat ve güncel olaylar gibi konuların üstesinden gelebilecekleri kadar yeterli dilsel araca sahiptirler; bunlar, kendilerini ifade edebilmek için yeterli olsa bile kelime dağarcıklarının yetersiz kaldığı durumlarla karşılaşabilir ve kelime tekrarlamaları yapabilir, bazen de anlatım zorlukları yaşayabilirler (2001; 2020).

Tahmin edilebilen günlük durumların dâhil olduğu durumların üstesinden gelebilecekleri kadar temel dilsel araç dağarcı̆̆ına sahiptirler ama istediklerini ifade ederken genelde söylemek istediklerinden ödün vermek ve istenilen kelimeyi aramak zorunda kalabilirler $(2001 ; 2020)$.

Basit ve somut gereksinimleri karşılamak amacıyla kişisel bilgiler, günlük alışkanlıklar, istekler ve ihtiyaçlar ve bilgi alma talepleri gibi konularda kısa günlük ifadeler üretebilirler (2001; 2020).

Temel cümle kalıplarını kullanarak ezberlenmiş ifadelerle; birkaç kelimeden oluşan kelime gruplarıla ve temel konuşma kalıplarıyla, kendilerinin ve diğer insanların neler yaptıkları, nelere sahip oldukları ve mekânlar gibi konularla ilgili iletişim kurabilirler (2001; 2020).

Günlük temel durumlara yetecek kadar kısa ve ezbere bildiği deyimlerden oluşan kısıtlı bir dağarcığa sahiptirler; olağan durumların dışında iletişim sık sık kesintiye uğrar ve anlaşmazlıklar ortaya çlkar (2001; 2020).

Kişisel bilgiler ve somut türden ihtiyaçlar hakkında çok temel bir dizi basit kelime dağarcığına sahiptirler (2001; 2020).

Tek yan cümlecikli cümlelerdeki temel yapıları, bazı unsurları yok sayarak ve çıkararak kullanabilirler (2020).

A1 Öncesi Kendileri hakkında basit bilgiler vermek için temel ifadeleri ve tek tük kelimeyi/işareti kullanabilirler (2020).

Tablo 1 incelendiğinde AOÖÇ (2020) Genel Dilsel Araçlar Alanı ölçeğinde yapılan değişikliklerin şu şekilde olduğu görülmektedir:

- C2 düzeyinde yeni bir tanımlayıcı eklenmemiştir. AOÖÇ (2001) tanımlayıcıları varlığını sürdürmektedir.

- C1 düzeyinde yeni bir tanımlayıcı bulunmaktadır. AOÖÇ (2001) tanımlayıcısı varlığını sürdürmektedir.

- B2 düzeyinde yeni bir tanımlayıcı tespit edilmemiştir. AOÖÇ (2001) tanımlayıcıları varlığını sürdürmektedir.

- B1 düzeyinde yeni bir tanımlayıcı tespit edilmemiştir. AOÖÇ (2001) tanımlayıcıları varlığını sürdürmektedir.

- A2 düzeyinde yeni bir tanımlayıcı tespit edilmemiştir. AOÖÇ (2001) tanımlayıcıları varlığını sürdürmektedir.

- A1 düzeyinde yeni bir tanımlayıcı bulunmaktadır. AOÖÇ (2001) tanımlayıcısı varlığını sürdürmektedir.

- $\quad$ A1 Öncesi dil düzeyi, ölçekte yenilik olarak tespit edilmekte ve bu düzeye yönelik bir tanımlayıcı bulunmaktadır.

\subsection{Kelime dağarcığı alanı ölçeğinde yapılan güncellemeler}

Bu ölçek, kullanılan ifadelerin genişliği ve çeşitliliği ile ilgilidir. Genellikle geniş çaplı okumalar yaparak edinilir. Ölçekte işlevselleştirilen temel kavramlar şunları içerir:

- $\quad$ Düzey aralığı: A1'den B2'ye, sonra sınırsız;

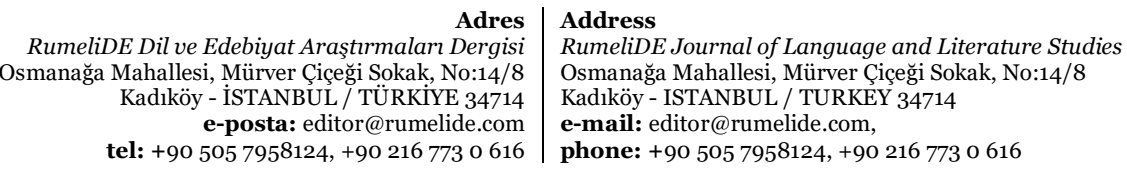


Analyzing the linguistic competencies contained in the 2020 Common European Framework of Refrence (CEFR) / G. H. Demirdöven (pp. 339-351)

- $\quad$ Dil türü: Temel bir kelime/işaret 4ve deyim dağarcı̆̆ından; deyimsel ifadeler ve konuşma dilini içeren çok geniş bir kelime dağarcığı dağarcığına (AOÖÇ, 2020).

Tablo 2'de Kelime Dağarcı̆̆ı Alanı ölçeğine yer verilmiştir.

Tablo 2. Kelime dağarcığı alanı (AOÖÇ, 2020, s. 131).

C2 Çok zengin bir kelime dağarcığına, deyim bilgisine ve günlük anlatım tarzlarına hâkimdirler ve ince anlam farklılıklarını ayırt edebilirler $(2001 ; 2020)$.

Geniş bir kelime dağarcı̆̆ına hâkimdirler ve bilmedikleri kelimeler yerine zorlanmadan başka kelimeleri kullanarak açığı kapatabilir; çok nadir kelime arar ya da bilmediği bir şeyi kullanmaktan kaçınırlar (2001; 2020).

C1 Daha az karşılaşılan kelimelerin/işaretlerin eş anlamlılarını kullanarak hemen hemen tüm durumlarda çeşitli kelime seçenekleri arasından seçim yapabilirler (2020).

Deyim ve günlük anlatımlara oldukça hâkimdir, kelimeleri ustaca kullanabilirler (2001; 2020) Uzmanlık alanlarında sık rastlanan çeșitli teknik kelime ve deyimsel ifadeleri anlayabilir ve bunları uygun şekilde kullanabilirler (2020).

Kendi uzmanlık alanları ve birçok genel alana yönelik konulara ilişkin geniş bir kelime dağarcığına sahiptirler (2020).

İlgi alanları doğrultusundaki konularda ve çoğu genel konuda iyi bir kelime dağarcığına sahiptirler (2001; 2020).

Tekrarlamaları sık sık kullanmamak için değişik ifadelere başvurabilirler ama yine de kelime dağarcıklarındaki eksiklikler, duraklamaya ve başka tanımlamalar aramaya yol açabilir (2001; 2020).

Pek çok kelimenin/işaretin uygun eş dizimlerini çoğu bağlamda oldukça sistematik bir şekilde üretebilirler (2020).

Alanlarında uzmanlık gerektiren kelime dağarcı̆̆ının çoğunu anlayabilir ve kullanabilirler ancak alanları dışındaki uzmanlık terim dizinleri ile sorunları vardır (2020).

Bilindik konular ve günlük durumlarla ilgili geniş bir kelime dağarcığına sahiptirler (2020).

B1 Aile, hobiler ve ilgi alanları, meslek, seyahat ve güncel olaylar gibi günlük yaşamla ilgili çoğu konuda kendilerini, bazı dolaylı anlatımlarla ifade edebilecek kadar yeterli kelime dağarcığına sahiptirler (2001; 2020).

Bilindik durum ve konuları içeren alışılagelmiş, günlük işlemleri yürütmek için yeterli kelime dağarcı̆̆ına sahiptirler (2001; 2020).

A2

Temel iletişim ihtiyaçlarının ifade edilmesi için yeterli kelime dağarcı̆̆ına sahiptirler (2001; 2020).

Basit ve temel yaşamsal ihtiyaçlarının üstesinden gelmek için yeterli bir kelime dağarcığına sahiptirler (2001; 2020).

A1 Bazı somut durumlara ilişkin kelime/işaret ve deyimlerden oluşan temel bir kelime dağarcığına sahiptirler (2001; 2020).

A1 Öncesi Mevcut bir tanımlayıcı bulunmamaktadır (2020).

Tablo 2 incelendiğinde AOÖÇ (2020) Kelime Dağarcığı Alanı ölçeğinde yapılan değiş̧ikliklerin şu şekilde olduğu görülmektedir:

- AOÖÇ (2020) Kelime Dağarcı̆̆ı Alanı ölçeğinde bulunan tanımlayıcılarda yapılan değişiklikler şu şekildedir:

- C2 düzeyinde yeni bir tanımlayıcı tespit edilmemiştir. AOÖÇ (2001) tanımlayıcısı varlığını sürdürmektedir.

- C1 düzeyinde yeni iki tanımlayıcı bulunmaktadır. AOÖÇ (2001) tanımlayıcıları varlığını sürdürmektedir.

- B2 düzeyinde yeni üç tanımlayıcı bulunmaktadır. AOÖÇ (2001) tanımlayıcıları varlığını sürdürmektedir. Ayrıca, bu düzey en son sürümde iki kısma ayrılması bakımından da önem

RumeliDE Dil ve Edebiyat Araştırmaları Dergisi Osmanağa Mahallesi, Mürver Çiçeği Sokak, No:14/8 Kadıköy - ISTANBUL / TÜRKIYE 34714 e-posta: editor@rumelide.com tel: +90 $5057958124,+902167730616$
Address

RumeliDE Journal of Language and Literature Studies Osmanağa Mahallesi, Mürver Çiçeği Sokak, No:14/8

Kadıköy - ISTANBUL / TURKEY 34714

e-mail: editor@rumelide.com,

phone: +90 505 7958124, +90 2167730616 
taşımaktadır. Eklenen tamınylayıcıların biri B2 üst düzey kısma yönelik olarak oluşturulmuşken; diğer iki tanımlayıcı ise mevcut tanımlayıcı ile birlikte B2 alt düzey kısmında yer almaktadır.

- B1 düzeyinde yeni bir tanımlayıcı bulunmaktadır. AOÖÇ (2001) tanımlayıcısı varlığını sürdürmektedir.

- A2 düzeyinde yeni bir tanımlayıcı bulunmaktadır. AOÖÇ (2001) tanımlayıcıları varlığını sürdürmektedir.

- A1 düzeyinde yeni bir tanımlayıcı bulunmaktadır. AOÖÇ (2001) tanımlayıcısı varlığını sürdürmektedir.

- A1 Öncesi dil düzeyi, ölçekte yenilik olarak tespit edilmekte fakat bu düzeye yönelik mevcut bir tanımlayıcının bulunmadığı görülmektedir.

\subsection{Dilbilgisel doğruluk ölçeğinde yapılan güncellemeler}

Bu ölçek, hem kullanıcının/öğrencinin "önceden hazırlanmış" ifadeleri doğru hatırlama becerisiyle hem de düşünceyi ifade ederken dil bilgisel biçimlere odaklanma kapasitesiyle ilgilidir. Ölçekte işlevselleştirilen temel kavramlar şunları içerir:

- Belirli bir dağarcığın kontrolü (A1'den B1'e);

- Hataların belirginliği (B1'den B2'ye);

- $\quad$ Kontrol derecesi (B2'den C2'ye) (AOÖÇ, 2020).

Tablo 3’te Dilbilgisel Doğruluk ölçeğine yer verilmiştir.

Tablo 3. Dilbilgisel doğruluk (AOÖÇ, 2020, s. 132).

C2 Dikkat, birden fazla yöne ayrılmış olsa bile (Örn. ileriye dönük planlama, başkalarının tepkilerini izleme) karmaşık dil araçlarının dil bilgisel kontrolünü tutarlı bir şekilde sürdürürler (2001; 2020).

C1 Dil bilgisi kurallarına büyük ölçüde uyar; nadir olarak pek fark edilmeyecek hatalar yaparlar (2001; 2020).

Dil bilgisi kurallarına oldukça hâkimdirler; nadir olarak daha sonra düzeltilebilecek dil sürçmeleri ya da hatalar yaparlar; cümle yapılarında eksiklikler olabilir (2001; 2020).

Dil bilgisi kurallarına oldukça hâkimdirler; yanlış anlaşılmaya yol açacak hatalar yapmazlar (2001; 2020).

Karmaşık yapıları, bir miktar yanlışlıkla katı bir şekilde kullanma eğiliminde olsalar da basit dil yapılarına ve bazı karmaşık dil bilgisisi formlarına hâkimdirler (2020).

B1

Alışıldık durumlarla ilgili yeterli derecede doğru konuşarak anlaşabilir; ana dillerinin etkisi, belirgin olsa da genelde dil bilgisi yapılarına oldukça hâkimdirler (2001; 2020).

Genelde tahmin edilebilecek durumlarda sık kullanılan basmakalıp söz ve deyimleri içeren kelime dağarcığını, yeterli bir şekilde doğru olarak kullanabilirler (2001; 2020).

A2

Bazı basit yapıları, doğru olarak kullanabilirler ama yüklemleri kullanırken zamanları karıştırsalar ya da unutursalar özne-yüklem bağlantısını kurma esnasında sistematik temel yanlışlıklar yapsalar da ne demek istedikleri genellikle anlaşılır (2001; 2020).

A1 Birkaç basit dil bilgisi yapısını ve kalıp cümleleri kapsayan kısıtlı ve ezberlenmiş bir kelime dağarcığa sahiptirler (2001; 2020).

A1 Öncesi Kısa ifadelerde çok basit kelime/işaret kuralları prensiplerini kullanabilirler (2020).

Tablo 3 incelendiğinde AOÖÇ (2020) Dilbilgisel Doğruluk ölçeğinde yapılan değişikliklerin şu şekilde olduğu görülmektedir:

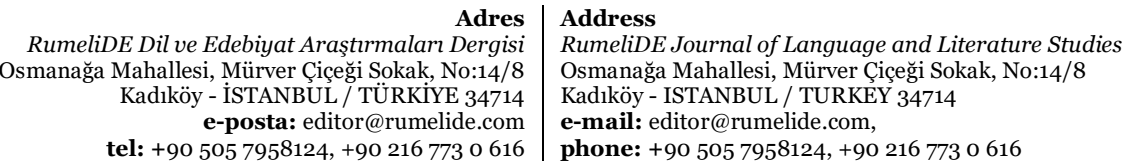


- C2 düzeyinde yeni bir tanımlayıcı tespit edilmemiştir. AOÖÇ (2001) tanımlayıcısı varlığını sürdürmektedir.

- C1 düzeyinde yeni bir tanımlayıcı tespit edilmemiştir. AOÖÇ (2001) tanımlayıcısı varlığını sürdürmektedir.

- B2 düzeyinde yeni bir tanımlayıcı bulunmaktadır. AOÖÇ (2001) tanımlayıcıları varlığını sürdürmektedir.

- B1 düzeyinde yeni bir tanımlayıcı tespit edilmemiştir. AOÖÇ (2001) tanımlayıcıları varlığını sürdürmektedir.

- A2 düzeyinde yeni bir tanımlayıcı tespit edilmemiştir. AOÖÇ (2001) tanımlayıcısı varlığını sürdürmektedir.

- A1 düzeyinde yeni bir tanımlayıcı tespit edilmemiştir. AOÖÇ (2001) tanımlayıcısı varlığını sürdürmektedir.

- A1 Öncesi dil düzeyi, ölçekte yenilik olarak tespit edilmekte ve bu düzeye yönelik bir tanımlayıcı bulunmaktadır.

\subsection{Kelime dağarcığı hâkimiyeti ölçeğinde yapılan güncellemeler}

Bu ölçek, kullanıcının/öğrencinin kelime dağarcığından uygun bir ifade seçme becerisiyle ilgilidir. Yetkinlik arttıkça bu tür bir beceri; bir ifadenin, diğerini tetiklemesi ile birlikte eş dizimler ve kelime grupları şeklindeki bir birliktelikle gittikçe daha fazla yönlendirilir. Ölçekte işlevselleştirilen temel kavramlar şunları içerir:

- Konulara aşinalık (A1'den B1'e);

- $\quad$ Kontrol derecesi (B2'den C2’ye) (AOÖÇ, 2020).

Tablo 4’te Kelime Dağarcı̆̆ı Hâkimiyeti ölçeğine yer verilmiştir.

Tablo 4. Kelime dağarcığı hâkimiyeti (AOÖÇ, 2020, s. 132).

C2 Kelime dağarcıklarını, sürekli olarak doğru ve uygun bir şekilde kullanırlar (2001; 2020).

C1 Kullanımı daha az yaygın olan kelimeleri, ana dilleri gibi ve bağlama uygun bir şekilde kullanırlar (2020).

Kelime kullanımı sırasında bazı küçük engellerle karşılaşmalarına rağmen önemli kelime hataları olmaz (2001; 2020).

B2 Kelimeleri, genellikle doğru olarak kullanırlar fakat iletişimi aksatmayacak şeklide bazı karışık ve yanlış kelime/işaret seçimleri, meydana gelir (2001; 2020).

B1 Karmaşık konularla ilgili olguları anlatmak ya da az bilindik konu ve durumlarla başa çımak için bazı temel yanlışlıklar yapmalarına rağmen temel kelime dağarcığına oldukça hâkimdirler (2001; 2020).

Bilindik konuları tartışırken çok çeşitli basit kelimeleri uygun şekilde kullanırlar (2020).

A2 Somut ve günlük ihtiyaçlarla ilgili kısıtlı bir kelime dağarcığına sahiptirler (2001; 2020).

A1 Mevcut bir tanımlayıcı bulunmamaktadır (2001; 2020).

A1 Öncesi Mevcut bir tanımlayıcı bulunmamaktadır (2020).

Tablo 4 incelendiğinde AOÖÇ (2020) Kelime Dağarcı̆̆ı Hâkimiyeti ölçeğinde yapılan değişikliklerin şu şekilde olduğu görülmektedir:

AOÖÇ (2020) Kelime Dağarcı̆̆ı Hâkimiyeti ölçeğinde bulunan tanımlayıcılarda yapılan değişiklikler şu şekildedir:

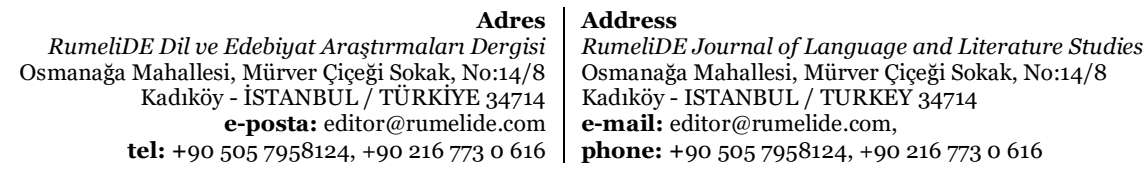


- C2 düzeyinde yeni bir tanımlayıcı tespit edilmemiştir. AOÖÇ (2001) tanımlayıcısı varlığını sürdürmektedir.

- C1 düzeyinde yeni bir tanımlayıcı bulunmaktadır. AOÖÇ (2001) tanımlayıcısı varlığını sürdürmektedir.

- B2 düzeyinde yeni bir tanımlayıcı tespit edilmemiştir. AOÖÇ (2001) tanımlayıcısı varlı̆ı̆ıı sürdürmektedir.

- B1 düzeyinde yeni bir tanımlayııı bulunmaktadır. AOÖÇ (2001) tanımlayıcısı varlığını sürdürmektedir.

- A2 düzeyinde yeni bir tanımlayıcı tespit edilmemiştir. AOÖÇ (2001) tanımlayıcısı varlı̆̆ını sürdürmektedir.

- A1 düzeyinde yeni bir tanımlayıcı tespit edilmemiştir.

- A1 Öncesi dil düzeyi, ölçekte yenilik olarak tespit edilmekte fakat bu düzeye yönelik mevcut bir tanımlayıcının bulunmadı̆̆ı görülmektedir.

\subsection{Sesbilgisel hâkimiyet ölçeğinde yapılan güncellemeler}

AOÖÇ'de (2020) , 2001 ylında yayınlanan tanımlayıcıların arkasındaki orijinal araştırmada kalibre edilen ölçekler arasında en az başarılı olanının Sesbilgisel Hâkimiyet ölçeği olduğu vurgulanarak 2020 sürümünde bu ölçekteki tanımlayıcıların sıfırdan ele alınarak değiştirildiği vurgulanmaktadır.

Ölçekte işlevselleştirilen temel kavramlar şunları içerir:

- Anlaşlabilme: Konuşmacının mesajını çözmek için muhataptan ne kadar çaba sarf etmesi gerektiği;

- Konuşulan diğer dillerin etkisinin kapsamı;

- Seslerin kontrolü;

- Bürün bilimsel özelliklerin kontrolü (AOÖÇ, 2020).

Tablo 5’te Sesbilgisel Hâkimiyet ölçeğine yer verilmiştir.

Tablo 5. Sesbilgisel hâkimiyet (AOÖÇ, 2020, s. 134-135).

\section{Genel sesbilgisel hâkimiyet}

Hedef dilde kelime ve cümle vurgusu, ritim ve tonlama gibi bürünsel özellikler dâhil olmak üzere tüm ses bilimsel özellikleri oldukça kontrollü bir şekilde kullanabilirler, böylece ilettikleri mesajların ince noktaları, açıklık ve kesinlik kazanır. Anlaşılabilirlik, etkili aktarım ve anlam geliştirme ve diğer dil(ler)den etkilenilebilecek aksan özelliklerinden hiçbir şekilde etkilenmezler (2020).

Hedef dilde, anlaşılırlığı sağlamak için yeterli kontrol ile tüm ses bilimsel özellikleri kullanabilirler.

C1

\section{Ses artikülasyonu}

Hedef dilin neredeyse tüm seslerini açık ve hassas bir şekilde ifade edebilirler (2020).

Hedef dilin neredeyse tüm seslerini oldukça kontrollü bir şekilde ifade edebilirler. Bir sesi fark edilir şekilde yanlıș telaffuz ederlerse genellikle kendilerini düzeltebilirler (2020).

\section{Bürünsel özellikler}

İnce anlam farklılıklarını iletmek için (Örn. ayırt etmek ve vurgulamak) bürünsel özellikleri (örneğin vurgu, ritim ve tonlama) uygun ve etkili bir şekilde kullanabilirler (2020).
Anlassılabilirliği veya etkinliği etkilemeyen stres, ritim ve/veya tonlamanın kontrolünde yalnızca ara sira yapılan hatalarla düzgün, anlaşılır sözlü söylem üretebilirler (2020). etkilenmiş bazı aksan(lar)ın özellikleri fark edilebilirler; bu

Adres

RumeliDE Dil ve Edebiyat Araştırmaları Dergis Osmanağa Mahallesi, Mürver Çiçeği Sokak, No:14/8 Kadıköy - ISTANBUL / TÜRKIYE 34714 e-posta: editor@rumelide.com tel: +90 $5057958124,+902167730616$
Address

RumeliDE Journal of Language and Literature Studies Osmanağa Mahallesi, Mürver Çiçeği Sokak, No:14/8

Kadıköy - ISTANBUL / TURKEY 34714

e-mail: editor@rumelide.com,

phone: +90 5057958124, +90 2167730616 
durum, anlaşılabilirliği etkilemez (2020).

Genellikle uygun tonlamayı kullanabilir; vurguyu doğru bir şekilde yerleştirebilir ve farklı sesleri açık bir şekilde ifade edebilirler; aksan, konuştukları diğer dil(ler)den etkilenme eğilimindedir ancak bu durumun, anlaşılabilirlik üzerinde çok az etkisi vardır veya hiç etkisi yoktur (2020).

Telaffuzları genellikle anlaşılırdır; hem söyleyiş hem de kelime seviyelerinde tonlama ve vurgu, mesajın anlaşılmasını engellemez (2020).

Vurgu, genellikle kişilerin konuştukları diğer dillerden etkilenir (2020).

Telaffuz, genellikle anlaşılacak kadar açıktır ancak konuşma eşlerinden zaman zaman tekrar etme istemeleri gerekecektir. Konuştukları diğer dil(ler)in vurgu, ritim ve tonlama üzerindeki güçlü etkisi; muhatapların iş birliğini gerektirerek anlaşılabilirliği etkileyebilir. Yine de bilindik kelimelerin telaffuzu açıktır (2000).
Hedef dildeki seslerin çoğunu, uzun bir üretim sürecinde birkaç sistematik yanlış telaffuza rağmen açı bir şekilde seslendirebilirler (2020).

Bilinmeyen kelimelerin çoğunun ses bilimsel özelliklerini (Örn. kelime vurgusu), makul bir doğrulukla (Örn. okurken) tahmin etmek için dağarcıklarından genelleme yapabilirler (2020).

Daha az aşina olunan ses ve kelimeler düzenli olarak yanlış telaffuz edilmesine rağmen sesletim genellikle baştan sona anlaşılırdır (2020).

Konuşmacının belirli sesleri anlamak için çaba göstermesi koşuluyla basit, günlük durumlarda iletişim kurarken telaffuz genellikle anlaşılırdır (2020).

Sesbirimlerinin sistematik olarak yanlış telaffuz edilmesi, muhatap

konuşmacının art alan bilgisinin telaffuz üzerindeki etkisini tanımaya ve buna uyum sağlamaya çalıştığı sürece anlaşılabilirliğ $\mathrm{i}$ engellemez (2020).

Dikkatlice yönlendirilirse sesleri, hedef dilde yeniden üretebilirler (2020).

Sinırlı sayıda sesi ifade edebilirler, böylece konuşma yalnızca muhatap destek sağladığında anlaşılabilir (Örneğin, doğru şekilde tekrarlayarak ve yeni seslerin tekrarını yaparak) (2020).
Söylediklerini eksiksiz şekilde ifade etmek için tonlamayı değiştirebilir ve vurguyu doğru şekilde yerleştirebilirler (2020).

İletmek istedikleri mesajı desteklemek için bürünsel özellikleri (Örneğin; vurgu, tonlama, ritim) kullanabilir, ancak konuştukları diğer dillerden biraz etkilenebilirler (2020).

Konuştukları diğer dil(ler)in vurgu, tonlama ve/veya ritim üzerindeki güçlü etkisine rağmen mesajlarını anlaşılır bir şekilde aktarabilirler (2020).

Konuştukları diğer dil(ler)de vurgu, tonlama ve/veya ritim üzerinde güçlü bir etkiye sahip olmasına rağmen günlük dilde kullanılan kelime ve cümlelerin bürünsel özelliklerini anlaşılır bir şekilde kullanabilirler (2020). Bürünsel özellikler (örneğin kelime vurgusu), bilinen günlük ve basit kelimeler için yeterlidir (2020).

Sinırlı bir basit kelime ve kelime öbeği dağarcı̆̆ının bürünsel özelliklerini anlaşılır bir şekilde kullanabilirler, konuştukları diğer dil(ler)den stres, ritim ve/veya tonlamaya yönelik olarak etkilenirler, muhataplarının iş birliğine dayalı olması gerekir (2020). ve ifadeler için vurgu yapabilirler (2020).
Adres

RumeliDE Dil ve Edebiyat Araştırmaları Dergis Osmanağa Mahallesi, Mürver Çiçeği Sokak, No:14/8 Kadıköy - ISTANBUL / TÜRKIYE 34714 e-posta: editor@rumelide.com tel: +90 $5057958124,+902167730616$
Address

RumeliDE Journal of Language and Literature Studies Osmanağa Mahallesi, Mürver Çiçeği Sokak, No:14/8

Kadıköy - ISTANBUL / TURKEY 34714

e-mail: editor@rumelide.com,

phone: +90 5057958124, +90 2167730616 
Tablo 5 incelendiğinde AOÖÇ (2020) Sesbilgisel Hâkimiyet ölçeğinde yapılan değişikliklerin şu şekilde olduğu görülmektedir:

- AOÖÇ’de (2001) Sesbilgisel Hâkimiyet başlı̆ı altında C2 ve C1 düzeylerinde aynı olmak üzere C2-A1 arası her düzeyde bir tanımlayıcı olacak şekilde toplam 6 tanımlayıcı bulunmaktadır.

- AOÖÇ’ de (2020) ise Sesbilgisel Hâkimiyet başlı̆̆ı; Genel Sesbilgisel Hâkimiyet, Ses Artikülasyonu ve Bürünsel Özellikler olmak üzere 3 alt başlık altında ele alınmıştır. Genel Sesbilgisel Hâkimiyet alt başlı̆ı altında 6 (A1-C2) ; Ses Artikülasyonu alt başlı altında 9; (A1-C2) ve Bürünsel Özellikler alt başlğı altında ise 8 (A1-C2) olmak üzere toplam 23 tanımlayıcı bulunmaktadır.

\subsection{Yazım yeterliği hâkimiyeti ölçeğinde yapılan güncellemeler}

$\mathrm{Bu}$ ölçek, metin düzeni ve noktalama işaretlerini taklit etme ve kullanma becerisiyle ilgilidir. Ölçekte işlevselleştirilen temel kavramlar şunları içerir:

- Kelime ve cümlelerin taklit edilmesi (daha düşük seviyelerde);

- Yazım;

- Yazım, noktalama işaretleri ve metin düzeni karışımıyla anlaşılırlı (AOÖÇ, 2020).

Tablo 6'da Yazım Yeterliği Hâkimiyeti ölçeğine yer verilmiştir.

Tablo 6. Yazım yeterliği hâkimiyeti (AOÖÇ, 2020, s. 136).

C2 Yazılı metinlerde yazım hatası bulunmaz (2001; 2020).

C1 Tasarım, paragraf ve noktalama işaretleri, yazım için tutarlı ve yararlıdır (2001; 2020). Nadir yapılan hatalar dışında yazım doğrudur (2001; 2020).

B2 Alışılagelmiş yazı düzeni ve paragraf kurallarına uygun olarak birbiriyle bağlantılı, açık ve anlaşılır bir şekilde yazabilir (2001; 2020).

İmla ve noktalama işaretleri kurallarını, yeterli derecede doğru kullanır; fakat ana dilinin etkisine de rastlanır (2001; 2020).

B1 Anlaşılır, bağlantılı metinler yazabilir (2001; 2020).

İmla ve noktalama, paragraf ve düzenleme kuralları, genelde anlamayı sağlayacak derecede doğrudur $(2001 ; 2020)$.

Yol tarifi gibi günlük konulara yönelik kısa cümleleri, bakarak yazabilir (2001; 2020).

Kelime dağarcığındaki kısa kelimeleri sesletime uygun olarak doğru yazar (Ancak alışılmış yazım kurallarını kullanmaz) (2001; 2020).

Basit tabelalar ya da talimatlar, günlük nesnelerin adları, mağazaların adları ve düzenli olarak kullanılan kalıp cümleler gibi tanıdık kelime ve kısa cümleleri bakarak yazabilir $(2001 ; 2020)$.

Adresini, milletini ve diğer kişisel bilgilerini harf harf söyleyebilir (2001; 2020).

Temel noktalama işaretini kullanabilir (Örn. nokta işareti, soru işareti) (2020).

A1 Öncesi Mevcut bir tanımlayıcı bulunmamaktadır (2020).

Tablo 6 incelendiğinde AOÖÇ (2020) Yazım Yeterliği Hâkimiyeti ölçeğinde yapılan değişikliklerin şu şekilde olduğu görülmektedir:

- C2 düzeyinde yeni bir tanımlayıcı tespit edilmemiştir. AOÖÇ (2001) tanımlayıcısı varlığını sürdürmektedir.

- C1 düzeyinde yeni bir tanımlayıcı tespit edilmemiştir. AOÖÇ (2001) tanımlayıcıları varlığını sürdürmektedir.

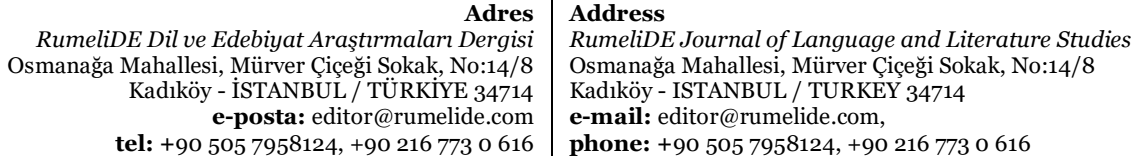

RumeliDE Journal of Language and Literature Studies

Osmanağa Mahallesi, Mürver Çiçeği Sokak, No:14/8

Kadıköy - ISTANBUL / TURKEY 34714

e-mail: editor@rumelide.com,

phone: +90 5057958124 , +90 2167730616 
- B2 düzeyinde yeni bir tanımlayıcı tespit edilmemiştir. AOÖÇ (2001) tanımlayıcıları varlığını sürdürmektedir.

- B1 düzeyinde yeni bir tanımlayıcı tespit edilmemiştir. AOÖÇ (2001) tanımlayıcıları varlı̆̆ını sürdürmektedir.

- A2 düzeyinde yeni bir tanımlayıcı tespit edilmemiştir. AOÖÇ (2001) tanımlayıcıları varlığını sürdürmektedir.

- A1 düzeyinde yeni bir tanımlayıcı bulunmaktadır. AOÖÇ (2001) tanımlayıcıları varlığını sürdürmektedir.

- A1 Öncesi dil düzeyi, ölçekte yenilik olarak tespit edilmekte fakat bu düzeye yönelik mevcut bir tanımlayıcının bulunmadığı görülmektedir.

\section{Sonuç, tartışma ve öneriler}

AOÖÇ 2001 ve 2020 sürümleri dilbilgisel yeterlikler bağlamında ele alındığında AOÖÇ 2020 sürümünde (C2: 4; C1: 7; B2: 8; B1: 5; A2: 5; A1; 6 ve A1 Öncesi: 2) 37 yeni tanımlayıcı bulunduğu ve son sürümde verilen tanımlayıcıların cinsiyetten bağımsız ve kapsayıcı kiplikte olmasını sağlamak için biçimlendirmelerde çeşitli küçük değişiklikler yapıldığı görülmektedir. Eklenen tanımlayıcıların \%35'erinin temel dil kullanımı ve bağımsız dil kullanımı; \%30'unun ise yetkin dil kullanımı düzeylerinde olduğu tespit edilmiştir. Bu doğrultudan yola çıkarak eklenen tanımlayıcıların düzeyler arasında dengeli bir dağılım sergilediğini söyleyebiliriz.

Ayrıca AOÖÇ (2001) sürümünde dilbilgisel yeterlikler kapsamındaki ölçeklerde A1 Öncesi dil düzeyi bulunmazken; AOÖÇ (2020) sürümünde ise Sesbilgisel Hâkimiyet ölçeği hariç diğer ölçeklere A1 Öncesi dil düzeyinin eklendiği ve bu dil düzeyine ilişkin 2 adet tanımlayıcının bulunduğu tespit edilmiştir. Söz konusu iki tanımlayıcı da şekil ve görsellerin kelimelerle ilişkilendirilmesine yönelik tanımlayıcılar olması bakımından önem taşımaktadır.

AOÖÇ'de (2020) dilbilgisel yeterlikler bağlamında verilen ölçekler, tanımlayıcı düzeyinde yapılan güncellemeler bağlamında ele alındığında en fazla güncelleme yapılan ölçeğin Sesbilgisel Hâkimiyet ölçeği olduğu görülmektedir. AOÖÇ’de (2020), verilen sesbilgisel tanımlayıcılar; açık, kapsamlı ve ikinci/yabancı dil eğitiminin çeşitli sesbilgisel yönlerine ilişkin daha yeni düşünceleri kapsayacak şekilde genişletilmiştir. Dolayısıyla AOÖÇ (2020) sürümüyle süreç içerisinde değişen ve çeşitlenen dil ihtiyaçlarına daha uygun tanımlayıcıların sunulduğunu söylemek mümkündür.

Türkçe'nin yabancı dil olarak öğretimi alanında yapılacak olan uygulamaların AOÖÇ ile uyumlu olması ve yabancı dil öğretiminde kullanılan dil öğretim setlerinin ve diğer materyallerin AOÖÇ ölçüt alınarak hazırlanılmasının (Tanrıkulu ve Şıhanlıŏlu, 2019) dil öğretimi süreci sonucunda ortaya çıacak çıktının kalitesini arttıracağı düşünülmektedir. Bu bağlamdan yola çıarak dilbilgisel yeterlikler kapsamında sunulan yeni dil düzeyi ve tanımlayıcıların yabancı dil olarak Türkçe öğretimi sürecine dâhil edilmesinin öğrencilerin; genel dil kullanımı, kelime dağarcığı, dilbilgisel doğruluk, kelime dağarcı̆̆ hâkimiyeti, sesbilgisel hâkimiyet ve yazım yeterliği hâkimiyeti alanlarında daha etkin bir dil kullanımı gerçekleştirmesine altyapı oluşturacağını söyleyebiliriz.

AOÖÇ’nin son sürümünün, yenilik ve eklemeler yoluyla genişletilerek ilk sürümünden daha kapsamlı bir hale getirilmesinden hareketle ilgili yenilik ve eklemeler üzerine yapılan çalışmaların sayısının arttırılarak Türkçenin yabancı dil olarak öğretiminde eksik kalan noktalar araştırılması, AOÖÇ ile ilgili yapılacak çalışmalara öneri olarak sunulabilir.

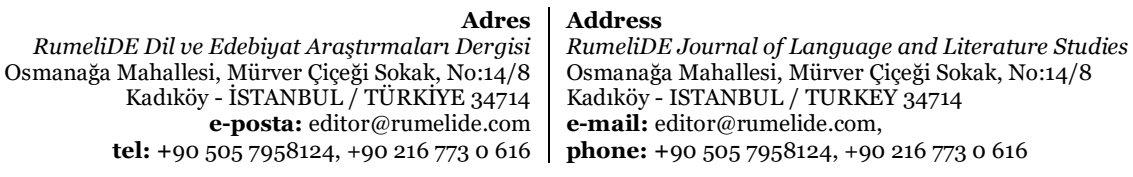




\section{Kaynakça}

Alderson, C. C. (2007). The CEFR and the need for more research. Modern Language Journal, 91(4), 629-663. DOI: 10.1111/j.1540-4781.2007.00627_4.x

CEFR. (2001). Common European framework of reference for languages: learning, teaching, assessment. Cambride: Cambride University Press.

CEFRCV. (2020). Common European framework of reference for languages: learning, teaching, assessment. Companion volume. Strasbourg: Council of Europe Publishing.

de Vaus, D.A. (2001). Research design in social research. London: Sage Publications.

Hassan, B. A. (2001). New trends in teaching grammar in the secondary school: A Review Article. ERIC, 1-31. ED454727.

Peçenek, D. (2008). Yabancı dil öğretiminde dilbilgisi. A.̈̈. Dil Dergisi, 141, 67-84. DOI: 10.1501/Dilder_0000000099

Tanrıkulu, L. ve Şıhanlıŏlu, Ö. (2019). 2018 (CEFR) Diller için Avrupa Ortak Öneriler Çerçevesi Yeni Açılamalar metininde konuşma becerisinin incelenmesi. IJLET, 7(4), 212-224. DOI: 10.29228/ijlet.39833

TELC. (2013). Diller için Avrupa ortak öneriler çervesi: öğrenim, öğretim ve değerlendirme (2. bs.).Almanya: Telc GmbH.

Wach, E. (2013). Learning about qualitative document analysis. https://opendocs.ids.ac.uk/opendocs/bitstream/handle/20.500.12413/2989/PP\%20InBrief\% 2013\%20QDA\%20FINAL2.pdf?sequence=4 adresinden 12.09.2021 tarihinde erişilmiştir.

Wisniewski, K. (2014). Die Validität der Skalen des Gemeinsamen europäischen Referenzrahmens für Sprachen. Frankfurt: Peter Lang.

Yıldırım, A. ve Şimşek, H. (2016). Sosyal bilimlerde nitel araştırma yöntemleri. Ankara: Seçkin.

RumeliDE Dil ve Edebiyat Araştırmaları Dergisi Osmanağa Mahallesi, Mürver Çiçeği Sokak, No:14/8 Kadıköy - İSTANBUL / TÜRKIYE 34714 e-posta: editor@rumelide.com tel: +90 $5057958124,+902167730616$
Address

RumeliDE Journal of Language and Literature Studies Osmanağa Mahallesi, Mürver Çiçeği Sokak, No:14/8

Kadıköy - ISTANBUL / TURKEY 34714

e-mail: editor@rumelide.com,

phone: +90 $5057958124,+902167730616$ 